\section{'Wuzhi No 3' Kiwifruit}

\section{Zhengwang Jiang, Shengmei Wang, Renhuang Huang, Zhonghui Zhang, and Hongwen Huang ${ }^{1}$ \\ Wuhan Botanical Garden, The Chinese Academy of Sciences, Wuhan, Hubei 430074, P.R. China}

The genus Actinidia is native to China and has been developed as one of the most successfully domesticated fruit trees in the 20th century. Actinidia chinensis Planch. and A. deliciosa (A. Chev.) C.F. Liang et A.R. Ferguson are the two most important species for international commerce and still have many wild fruit vines in naturally distributed locations (Cui et al., 2002), which can produce large fruit with high potential for horticultural use. Comparing with A. deliciosa, A. chinensis is more precocious and productive, and fruit of $A$. chinensis are more attractive in appearance with less pubescence on the fruit skin, higher vitamin $\mathrm{C}(\mathrm{Vc})$ content, and more variations of flesh color, i.e., green, light-yellow, golden-yellow, yellow-white, red, etc. (Huang et al., 2003). Thus, A chinensis is suitable for both the fresh market and processing. Kiwifruit breeders worldwide are now paying more and more attention to $A$. chinensis because of its superior quality and consistent inheritance of agronomically important traits (Huang et al., 2004). 'Wuzhi No 3' (Fig. 1) is a cultivar selected from $A$. chinensis with superior fruit quality and performance.

\section{Origin}

Central China is the center of speciation in the genus Actinidia because of its unique climactic and ecological conditions. In the early 1980s, experts from Wuhan Botanical Garden (WBG), the Chinese Academy of Sciences, conducted a field survey for Actinidia in Central China (including Hubei, Jiangxi provinces, etc.), and explored a large number of natural locations in the Mufu Mountains, including Tongshan county, Hubei province, and Wuning county of Jiangxi province (southeast to Hubei) for selecting superior strains. 'Wuzhi No 3' was found in a natural habitat with 930 m elevation in Wuning county and labeled as 'Wuzhi 81-36' in 1981. The ecological environment, other pistillate vines, and natural pollenizers were investigated and further survey was carried out during the blossoming and fruiting periods. The grafted seedlings of 'Wuzhi 81-36' were then cultivated in WBG and introduced to different locations in Hubei province and the other 14 provinces around Central China for field trails. Nutrient content and fruit traits of 'Wuzhi 8136 ' were evaluated for three successive seasons

Received for publication 4 Feb. 2005. Accepted for publication 8 May 2005. The research was partially supported NSF of China (30070082) and CAS-project (KSCX2-SW-104, KSCX2-SW-320).

${ }^{1}$ Corresponding author. Professor of Plant Genetics and Breeding, Wuhan Botanical Garden, The Chinese Academy of Sciences, Wuhan, Hubei 430074, P.R. China; e-mail hongwen@public.wh.hb.cn. Crop Authority. from 1983-85. The performance of this vine was highly recommended by growers, and now the total area of cultivation has reached 733 ha. 'Wuzhi 81-36' was then renamed 'Wuzhi No 3' (Wang et al., 1988) and released in 1989 by the Hubei Committee of (Agricultural)

\section{Description}

Vine characteristics and productivity. Actinidia chinensis is normally diploid, but the tetraploid can occur naturally in the area where 'Wuzhi No 3' is found, and 'Wuzhi No 3 ' is one tetraploid A. chinensis. The vine of 'Wuzhi No 3' has sturdy 1-year-old shoots in red-brown color and older twigs in brown color. Lenticels on the twig are oval-oblong in shape. Leaves are big and thick in abovate shape, with a size of $14 \mathrm{~cm}$ long and $14 \mathrm{~cm}$ broad. The upper surface of leaves is dark green and leathery with shiny luster, which

Fig. 1. 'Wuzhi No 3' kiwifruit.

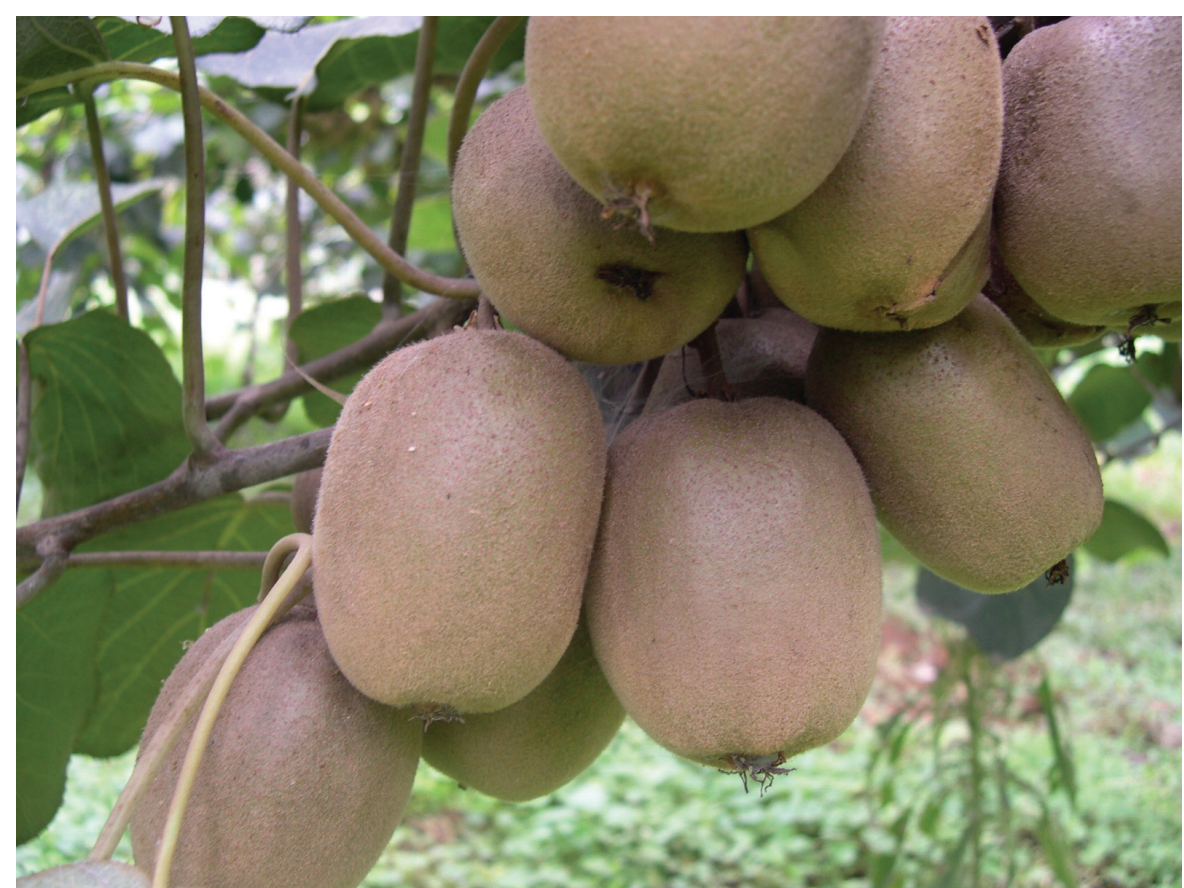

Table 1. Fruit setting characteristics of 'Wuzhi No 3'and other major cultivars.

\begin{tabular}{lcccc}
\hline Cultivar & $\begin{array}{c}\text { Budbreak } \\
(\%)\end{array}$ & $\begin{array}{c}\text { Fruiting } \\
\text { shoots } \\
(\%)\end{array}$ & $\begin{array}{c}\text { Fruit/ } \\
\text { inflorescence } \\
(\text { no. })\end{array}$ & $\begin{array}{c}\text { Inflorescence } \\
\text { position on } \\
\text { the shoots }\end{array}$ \\
\hline Wuzhi No 3 & $58.0 \mathrm{a}^{\mathrm{y}}$ & $69.0 \mathrm{a}$ & $3.9 \mathrm{a}$ & $1-8$ \\
Lushanxiang & $28.5 \mathrm{~b}$ & $25.0 \mathrm{~b}$ & $3.2 \mathrm{a}$ & $1-4$ \\
Hayward & $31.0 \mathrm{~b}$ & $10.0 \mathrm{~b}$ & $1.8 \mathrm{~b}$ & $2-5$ \\
\hline
\end{tabular}

${ }^{2}$ Data from Wuhan Botanical Garden, Wuhan, Hubei, P.R. China.

${ }^{y}$ Mean separation within columns by Duncan's multiple range test, $P \leq 0.05$. is a very distinct characteristic compared to other cultivars and may be helpful for a higher rate of budbreak and fruit setting (Table 1) The lower surface of the leaves is green with distinct veins. Leaves petioles are red, $7 \mathrm{~cm}$ long and $0.4 \mathrm{~cm}$ in diameter.

In Wuhan, Hubei, sap in the vine flows in the middle of February, and buds break in middle of March. Flower buds are composite, and budbreak rate and shoot-forming rate are high (Table 1). Emergence of new leaves is in the last $10 \mathrm{~d}$ of March. The blossom period is between end of April and early of May. Fruit ripens in late of September, and fruit growth span is 140 to $150 \mathrm{~d}$. Defoliation occurs in the first $10 \mathrm{~d}$ of December. Flowers are pistillate, in cyme inflorescence, mostly with three single flowers. Each flower has 5 to 6 petals that are 3.9 to $4.7 \mathrm{~cm}$ in diameter. The stamens produce onviable pollen.

The vine of 'Wuzhi No 3' is vigorous, with a high level of drought tolerance and pest and disease resistance. Thus, it grows fast and the canopy forms quickly. Normally, the vines will start to set fruit 2 years after planting with 1year-old grafted seedlings, and can get $4.5 \mathrm{~kg}$ in average per vine, and $12.5 \mathrm{~kg}$ for the third year. This cultivar is very productive, with consistent yield, and average production per hectare is around $39 \mathrm{t}$. Some mother fruiting shoots can form up to 16 shoots, bearing $>90$ fruit. Fruit-setting rate is $>62 \%$, and the lateral shoots with medium length ( 6 to $15 \mathrm{~cm}$ ) are the main fruit-bearing shoots. Shoots 8 to 9 years old still are able to bear fruit canes. 


\begin{tabular}{|c|c|c|c|c|c|c|c|c|c|c|c|c|}
\hline \multirow[b]{3}{*}{ Cultivar } & & & \multicolumn{2}{|c|}{$\begin{array}{c}\mathrm{Vc} \\
(\mathrm{mg} / 100 \mathrm{gFW})\end{array}$} & \multirow{3}{*}{$\begin{array}{l}\text { SSC } \\
(\%)\end{array}$} & \multirow{3}{*}{$\begin{array}{c}\text { Total } \\
\text { sugar } \\
(\%) \\
\end{array}$} & \multirow{3}{*}{$\begin{array}{c}\text { Amino } \\
\text { acid } \\
(\%)\end{array}$} & \multirow{3}{*}{$\begin{array}{c}\text { Titratable } \\
\text { acid } \\
(\%)\end{array}$} & \multirow{3}{*}{$\begin{array}{c}\text { Fruit } \\
\text { firmness } \\
(\mathrm{kgf})\end{array}$} & \multirow{2}{*}{\multicolumn{3}{|c|}{$\begin{array}{c}\text { Flesh } \\
\text { coloration }^{y}\end{array}$}} \\
\hline & \multicolumn{2}{|c|}{ Fruit $w^{\mathrm{z}}(\mathrm{g})$} & At & $\%$ Lost in & & & & & & & & \\
\hline & Max & Mean & harvest & 4 months & & & & & & $\mathrm{L}$ & $\mathrm{a}$ & $\mathrm{b}$ \\
\hline Wuzhi No 3 & $150 a^{x}$ & $85 \mathrm{a}$ & $275-300 a$ & $4.4 \mathrm{a}^{\mathrm{w}}$ & $15.2 \mathrm{a}^{\mathrm{v}}$ & $11.2 \mathrm{a}$ & $0.9-1.5 \mathrm{a}$ & $0.582 \mathrm{a}$ & $9.59 \mathrm{a}^{\mathrm{u}}$ & 61.3 & -12.8 & 39.8 \\
\hline Lushanxiang & $140 \mathrm{ab}$ & $87.5 \mathrm{a}$ & $128 \mathrm{~b}$ & $12 \mathrm{ab}$ & $9.5 \mathrm{~b}$ & $6.5 \mathrm{~b}$ & $1.7 \mathrm{a}$ & $0.550 \mathrm{a}$ & $8.76 \mathrm{ab}$ & --- & --- & --- \\
\hline Hayward & $120 \mathrm{~b}$ & $75 \mathrm{a}$ & $58-80 \mathrm{~b}$ & $23.0-41.0 \mathrm{~b}$ & $15.0 \mathrm{a}$ & $11.0 \mathrm{a}$ & $1.4 \mathrm{a}$ & $0.449 \mathrm{a}$ & $8.57 \mathrm{ab}$ & 62.3 & -15.3 & 35.5 \\
\hline Sanxia No 1 & $154 \mathrm{a}$ & $89 \mathrm{a}$ & $77 \mathrm{~b}$ & $2.2 \mathrm{a}$ & $9.6 \mathrm{~b}$ & $6.4 \mathrm{~b}$ & $1.6 \mathrm{a}$ & --- & $5.43 \mathrm{~b}$ & 89.2 & -4.4 & 9.3 \\
\hline Miliang No 1 & $128 \mathrm{~b}$ & $74 \mathrm{a}$ & $85 \mathrm{~b}$ & $23 \mathrm{~b}$ & $10.6 \mathrm{~b}$ & $7.1 \mathrm{~b}$ & $1.3 \mathrm{a}$ & --- & $7.77 \mathrm{~b}$ & 61.82 & -14.64 & 36.24 \\
\hline
\end{tabular}

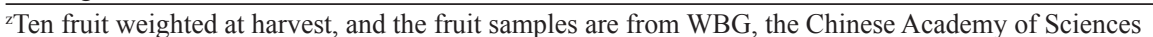

${ }^{y}$ Average of 10 fruit, measured by Minolta CR-300 chromameter at regular harvest time.

'Mean separation within columns by Duncan's multiple range test, $P \leq 0.05$.

${ }^{w} \mathrm{Vc}$ content was checked at regular ripen fruit, stored in refrigerator $\left(4\right.$ to $\left.8{ }^{\circ} \mathrm{C}\right)$ in plastic bags with ethylene absorb material.

vSSC measured with Atago refractometer at the soft stage, ready for eating, and so for the total sugar, titratable acid and amino acid test.

"Tested with a tip of $0.5 \mathrm{~cm}$ in diameter (Effegi FT327 penetrometer), with each fruit measured at both sides at harvest.

Fruit characteristics. Fruit of 'Wuzhi No 3 ' are big, with a mean weight of $85 \mathrm{~g}$ and maximum weight of $150 \mathrm{~g}$. Fruit size is about $6.3,5.4$, and $4.7 \mathrm{~cm}$ in longitudinal, latitudinal, and lateral dimension, respectively. Fruit are oval in shape, and the calix end is emarginate, the stem end truncate. Fruit have thin skin of dark green color, with shorter, softer pubescence (most shed when ripe) and yellow-brown spots. The flesh is green, juicy, and with tender in texture. The fruit are sweet with balanced sour content and a fragrant smell. The core of fruit is small, with over 37 carpels, and averages 550 seeds/fruit. Vc content is about 275 to $300 \mathrm{mg} / 100 \mathrm{~g}$ fresh fruit, which is three times higher than that in 'Hayward' and is among the top list of cultivars with high $\mathrm{Vc}$ content in A. chinensis (Table 2), which may be a benefit for processing. Fruit are considered top quality, with $15.2 \%$ soluble solids, $11.2 \%$ total sugar, $0.9 \%$ to $1.5 \%$ acids, and $17.7 \mathrm{~kg} \cdot \mathrm{cm}^{-2}$ firmness.

Fruit of 'Wuzhi No 3' are of high quality and can be used for both the fresh market and processing. One example is the fruit from an orchard in Sangzhi county, Hunan province, where $>6000$ vines of 'Wuzhi No 3' were grown during 1990s. Fruit were used for juice producing with a high rate, up to $80 \%$, of juice to fresh fruit. The juice produced in Sangzhi county won the golden prize of international agricultural products in Panama in 1991.

A fruit storage experiment was performed for 'Wuzhi No 3' and 'Hayward' in 2001 and 2003 following the international standard, with soluble solids content being $\geq 7 \%$ and $\geq 6.5 \%$, respectively, at the picking time. Fruit were kept in refrigerator (about $4{ }^{\circ} \mathrm{C}$ ) in plastic bags with ethylene absorbing agent. Nutrient contents were analyzed every 2 weeks, and Vc loss in 'Wuzhi No 3' was found much less than that in 'Hayward' (about 30\%).

\section{Performance}

With 'Wuzhi No 3' it is easy to get heavy fruiting, so it needs more fertilizer, which should mainly be organic. Thinning flowers and fruit is necessary, and planting density per hectare is suggested about 840 vines, and the suitable pollinizer is 'Moshan No4'. The winter pruning job should mainly focus on shearing of the extra shoots on the vine. 'Wuzhi No 3'could be adapted to a wide environmental range, and it was successfully introduced to different locations in Hubei, as well as other provinces, e.g., Hunan, Jiangxi, Shanxi, Fujian, Jiangsu, Zhejiang, Guangdong, Guangxi, etc.

The taste quality, appearance and storage quality of fruit would improve a lot when grown in locations with 500 to 1350 m elevations. For example, 'Wuzhi No 3' grown in Chaoyangping (1350 m above sea level), Jianshi county, Hubei province, had lighter green color than that in WBG, and even the top ends had green color. Meanwhile, fruit skin became thicker and fruit had longer storage life. Fruit picked in middle or late September can be kept $40 \mathrm{~d}$ under ambient temperature, with better flavor after storage due to increased $\mathrm{Vc}$ and total sugar content (30\% and 9\%, respectively). From 1983-85, fruit Vc content of 'Wuzhi No 3' grown in the Forestry Institute of Shiyan City, which is in the northwest of Hubei at about 700 to 800 m elevation, was $22 \%$ higher than that in WBG.

\section{Availability}

'Wuzhi No3' is available from WBG. This cultivar is registered or patented as 'Wuzhi No 3 ', and the seedlings can be provided by the Kiwifruit Research Center at WBG.

\section{Literature Cited}

Cui Z., H. Huang, and X. Xiao (eds.). 2002. Actinidia in China, p. 6-61. China Agr. Sci. Technol. Press, Beijing.

Huang, H., S. Wang, Z. Jiang, Z. Zhang, and J. Gong. 2003. Exploration of Actinidia genetic resources and development of kiwifruit industry in China. Acta Hort. 610:29-43.

Huang, H., Y. Wang, Z. Zhang, Z. Jiang, and S. Wang. 2004. Actinidia germplasm resources and kiwifruit industry in China. HortScience 39(6):1165-1172

Wang, S.M, R.H. Huang, X.W. Wu, and N. Kang. 1988. New selections of 'Wuzhi No 3' and 'Wuzhi No 2' from A. chinensis (in Chinese). China Fruits 4:6-8 